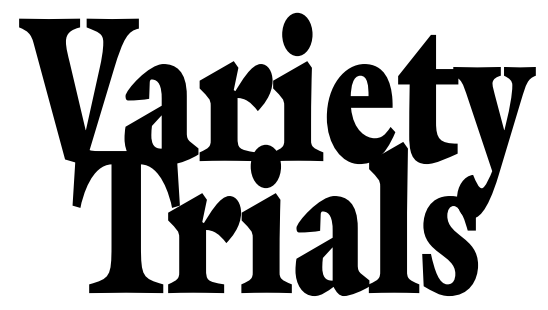

\section{Response of Chinese Cabbage Cultivars to Petiole Spotting and Bacterial Soft Rot}

\author{
John Warner, Ray Cerkauskas,
}

Tiequan Zhang, and Xiuming Hao

\section{Additional IndeX wORds. Brassica campestris ssp. pekinensis, Erwinia carotovora ssp. carotovora, nappa, gomasho, disease resistance}

\begin{abstract}
Summary. Nine chinese cabbage (Brassica campestris ssp. pekinensis group var. cephalata) cultivars were evaluated for petiole spotting (gomasho) and bacterial soft rot (caused by Erwinia carotovora ssp. carotovora) in 1999 and fifteen in 2000 and 2001. The cultivars were arranged in a randomized complete block design in a Granby sandy loam soil with six replications in 1999 and three replications in 2000 and 2001, at the Greenhouse and Processing Crops Research Centre, Harrow, Ontario, Canada. Plants were harvested in the fall of each year during two harvest periods, one for early-maturing cultivars, and one for late-maturing cultivars. At harvest, the percent bacterial soft rot, percent marketable heads, plant size, uniformity of harvest maturity, and the mean head weight were determined
\end{abstract}

\footnotetext{
$\overline{\text { Agriculture and Agri-Food Canada, Greenhouse and }}$ Processing Crops Research Centre, Harrow, Ontario, Canada N0R 1 G0.

We thank Jim Brown, Brian Hohner, and Mary-Anne Reeb for technical assistance. We also thank the Ontario Fruit and Vegetable Grower's Association for their financial support.
}

for each cultivar. The number and weight of spotted leaves was determined by rating ( 0 to 5 scale) each leaf. Petiole spotting was also rated following storage at $2{ }^{\circ} \mathrm{C}\left(36{ }^{\circ} \mathrm{F}\right)$ and $89 \% \pm 5 \%$ relative humidity for 3 to 4 weeks in 1999 and 2000. 'Yuki', 'Manoko', and 'Summer Top' had lowest losses from bacterial soft rot while 'Akala', 'Ohken 75', 'Spring Flavor', and 'Yuki' had low levels of petiole spotting. Cold storage increased the incidence of the spotting disorder for most cultivars.

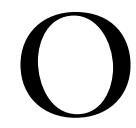
ne of the highest acreage oriental vegetable crops grown in Ontario is chinese cabbage (Shattuck and Shelp, 1986). It is widely used in Asian cuisine and also shipped to many markets in the United States. There are over 400 ha (988.4 acres) of chinese cabbage grown in southern Ontario with an estimated production of $5.7 \times 10^{6} \mathrm{~kg}$ (12.6 million $\mathrm{lb}$ ) and having an estimated farm value of $\$ 3.175$ million (Ontario Ministry of Agriculture and Food, 2000a). Little published information is available on the performance and disease resistance of chinese cabbage cultivars grown in Ontario (Cerkauskas et al., 1998; Shattuck and Shelp, 1986).

Petiole spotting, a disorder known in Japan as gomasho, has been reported in chinese cabbage in Ontario causing losses in quality (Cerkauskas et al., 1998). The symptoms occur in the field after head formation and continue to develop in storage. A large number of black spots, looking like sesame seeds, and about 1 to $2 \mathrm{~mm}$ ( 0.04 to 0.08 inches) in diameter, first appear on the midribs of outer heading leaves, then spread to the middle leaves. This disorder has substantial negative effects on quality (Kim and Klieber, 1997) and marketability of chinese cabbage. Chinese cabbage with acute black spots on the petioles in
Australia have been rejected from exports (Phillips and Gersbach, 1989).

Petiole spotting is believed to be caused by excessive nitrogen (Takahashi, 1981). In the leaves, absorbed nitrate is located in the midribs or veins, and it changes to amino acids in the leaf blades. However, excessive nitrate cannot be reduced fast enough to amino acid, and as a result, nitrite is produced as an intermediate in the midribs. The presence of nitrite has been detected before the spots are completely formed. Heavy nitrogen fertilizer applications, especially after head formation, accelerates this disorder (Phillips and Gersbach, 1989; Takahashi, 1981), and the number of spotted leaves and intensity of spotting increases on mature heads during cold storage (Phillips and Gersbach, 1989). Studies conducted in Japan and Australia have shown large cultivar differences in susceptibility to petiole spotting (Phillips and Gersbach, 1989; Takahashi, 1981). Cultivars that are resistant to petiole spotting have been used in commercial production; however, few of these cultivars are currently grown in Ontario.

Bacterial soft rot is a destructive disease of oriental crucifers, particularly chinese cabbage, in temperate areas of the world (Balvoll, 1995). Soft rot may also cause major losses to chinese cabbage in Ontario (Cerkauskas et al., 1998). The disease is most serious when high temperatures are combined with high humidity. Differences in cultivar susceptibility were reported (Balvoll, 1995; Fritz and Honma, 1987; Togashi, 1981) and breeding for resistance has been used as a method of control (Kikumoto, 1981; Nishi, 1981). Cultural practices such as growing on raised beds, adjusting planting dates to avoid warm temperatures at the heading stage and controlling insect vectors that disseminate the bacteria may also reduce the incidence of soft rot (Balvoll, 1995; Fritz and Honma, 1987; Kikumoto, 1981).

This study was conducted to identify fall-harvested, nappa-type, chinese cabbage cultivars that are resistant to petiole spotting and bacterial soft rot and that are suitable for commercial production in Ontario.

\section{Materials and methods}

Field trials were carried out in a Granby sandy loam soil at the Green- 
house and Processing Crops Research Centre, Harrow, Ontario, Canada. Nine chinese cabbage cultivars were evaluated in 1999 and fifteen in 2000 and 2001 as an fall-harvested crop. The cultivars were arranged using a randomized complete block design with six replications in 1999 and three replications in each of 2000 and 2001. Each plot was $6.0 \times 1.5 \mathrm{~m}(19.7 \times 4.9$ $\mathrm{ft}$ ) and contained two rows (24 plants). Plant spacing was $0.75 \mathrm{~m}$ (30 inches) between the rows and $0.5 \mathrm{~m}$ (20 inches) between plants within the row giving a plant population of 26,666 plants / ha (10,500 plants/acre).

Greenhouse-grown, 200-cell (TLC Polyform, Inc., Plymouth, Minn.) plug transplants were field-set using a two-row mechanical transplanter (RJ Equipment, Blenheim, Ont., Canada) on 9 Aug. 1999, 24 July 2000 , and 25 July 2001 . Ammonium nitrate fertilizer $(34 \mathrm{~N}-0 \mathrm{P}-0 \mathrm{~K})$ was applied at $200 \mathrm{~kg} \cdot \mathrm{ha}^{-1}(180 \mathrm{lb} /$ acre) nitrogen. One-third was applied preplant incorporated, one-third was side-dressed at the rosette stage and one-third was side-dressed after head formation. Phosphorous and potash were applied preplant incorporated according to soil test results. Weeds were controlled using preplant incorporated trifluralin at $0.6 \mathrm{~kg} \cdot \mathrm{ha}^{-1}(0.5$ $\mathrm{lb} / \mathrm{acre})$. Insect pests, including cabbage maggot (Delia radicum), were controlled with azinphos-methyl, carbaryl, cypermethrin and dimethoate (seven applications in 1999, six in 2000, and five in 2001). Plots were sprinkler irrigated three times in 1999, once in 2000 , and three times in 2001 with about $2.5 \mathrm{~cm}$ ( 1 inch) of water applied with each irrigation. Other cultural practices were similar to those recommended for Ontario (Ontario Ministry of Agriculture and Food, 2000b).

A once-over hand harvest for each cultivar was carried out when the majority of the heads for each cultivar were firm and of a suitable size or before severe freezing injury occurred

(1 Nov. 1999). There were two harvest periods each year, one for early maturing cultivars, and one for later maturing cultivars.

At harvest, all plants in each plot were visually rated for bacterial soft rot (percentage of all plants affected), plant size ( 1 to 5 rating: $1=$ low vigor, small plant size; $3=$ moderate vigor; and $5=$ very vigorous, large plant size), and in 2000 and 2001, uniformity of harvest maturity ( 1 to 5 rating: 1 = very uneven maturity (uneven head size); 3 = moderately even maturity and head size; and $5=$ all heads uniform in size). The total number of plants and number of marketable heads were counted to determine the percentage of marketable heads. Ten marketable heads, selected at random from each plot, were harvested and mean weight of marketable heads was determined. Head weight was determined after the outer wrap leaves were removed, similar to commercial harvest. Three heads per plot, selected at random, were rated for petiole spotting using a 0 to 5 rating (Fig. 1), where $0=$ no spot ting; 1 = trace of spotting on the petiole; 2 = some spots, scattered on the petiole; 3 = moderate level of spotting, spots concentrated in various parts of the petiole; $4=$ high incidence of spotting, sometimes spots coalescing, located throughout the petiole; and $5=$ extreme incidence of spotting with entire petiole affected. For each head, the number and weight of spotted leaves was recorded by examining each leaf and an average rating for spotted leaves was determined. Two or more heads from each plot were cut in half longitudinally to assess internal disorders. In 1999 and 2000, five heads from each plot were placed in a waxed cardboard box $[64 \times 31 \times 33 \mathrm{~cm}(25 \times$ $12 \times 13$ inches)] and held in cold storage at $2{ }^{\circ} \mathrm{C}$ and $89 \% \pm 5 \%$ relative humidity. After 3 to 4 weeks in storage, three of these heads, selected at random, were rated for petiole spotting as described previously.

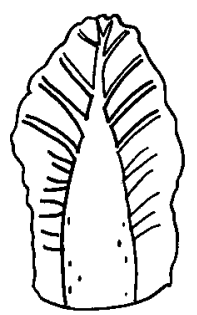

1

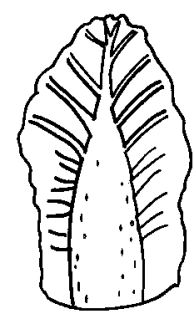

2

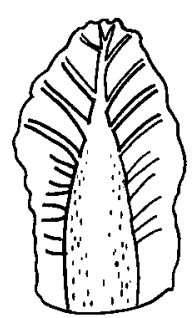

3

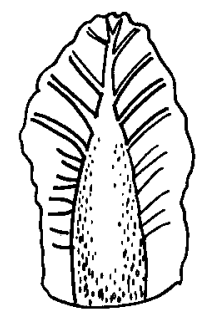

4

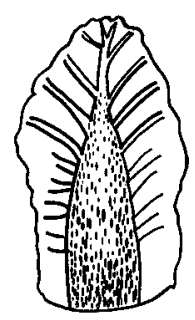

5
Data were analyzed as a randomized complete block design using the General Linear Model (PROC GLM) procedure in the SAS 6.1 package (SAS Institute, Inc., Cary, N.C.). When the GLM procedure indicated a significant effect $(P<0.05)$, means were separated using Fisher's least significant difference (FLSD) test $(P<0.05)$. The harvest and storage petiole spotting assessments (1999 and 2000) were evaluated using a pooled analyses of variance procedure for measurements over time from a randomized complete block design. When a significant interaction occurred $(P<0.05)$, the harvest and storage assessment times were analysed individually and the assessment times were compared for each cultivar. A correlation analysis (PROC CORR) was performed on plant size and head size to examine for significant relationships.

\section{Results and discussion}

Differences in cabbage head and plant size among years were related to temperature and rainfall conditions. The 1999 growing season was dry with above normal temperatures in September(Table 1). Although supplemental water was applied through irrigation, cabbage head weight and plant size were small in 1999 compared to 2000 and 2001 (Table 2), which were wetter growing seasons (Table 1 ). Head weights were more variable in $1999(\mathrm{CV}=27 \%)$ compared to 2000 $(\mathrm{CV}=6 \%)$ and $2001(\mathrm{CV}=9 \%$, Table 2$)$. The low percentage of marketable heads for some cultivars in 1999 (Table 2 ) was due to small head size resulting from the poor growing conditions and the late planting date (9 Aug. 1999). The planting date was 2 weeks earlier in 2000 and 2001, compared to 1999. Most of the unmarketable heads in 2000 were due to bacterial soft rot with some cultivars having more than $50 \%$ of the heads affected (Table 2 ). 'Nikko' had poor quality heads with multiple hearts in many heads and 'Optiko' had many heads with internal breakdown due to soft rot. The unmarketable heads in 2001 were due to soft rot and in some cases, small head size (Table 2).

'Ohken 75' had the largest head

Fig. 1.Petiole spotting (gomasho) rating for chinese cabbage from 1 (trace of spotting) to 5 (extreme incidence of spotting); 0 (no spotting), not shown. 
Table 1. Mean monthly temperature and rainfall during the chinese cabbage growing season ${ }^{\mathrm{z}}$ at Harrow, Ontario, 1999 to 2001.

\begin{tabular}{|c|c|c|c|c|c|c|c|c|}
\hline \multirow[b]{2}{*}{ Month } & \multicolumn{4}{|c|}{$\operatorname{Temp}\left({ }^{\circ} \mathbf{C}\right)^{\mathrm{y}}$} & \multicolumn{4}{|c|}{ Rainfall $(\mathbf{m m})^{y}$} \\
\hline & 1999 & 2000 & 2001 & $\begin{array}{c}\text { 10-year } \\
\text { mean }^{x}\end{array}$ & 1999 & 2000 & 2001 & $\begin{array}{l}\text { 10-year } \\
\text { mean }^{x}\end{array}$ \\
\hline August & 20.7 & 20.9 & 22.8 & 20.9 & 40.0 & 89.4 & 46.6 & 98.7 \\
\hline September & 18.6 & 16.9 & 16.6 & 17.3 & 37.0 & 73.2 & 114.8 & 88.2 \\
\hline October & 11.1 & --- & --- & 11.3 & 40.5 & --- & --- & 66.4 \\
\hline
\end{tabular}

${ }^{\mathrm{z}}$ Growing season from 9 Aug. to 1 Nov. 1999, 24 July to 28 Sept. 2000, and 25 July to 1 Oct. 2001.

$\mathrm{y} 1.8\left({ }^{\circ} \mathrm{C}\right)+32={ }^{\circ} \mathrm{F} ; 25.4 \mathrm{~mm}=1$ inch.

xTen-year mean, 1990 to 1999.

size $[1.65 \mathrm{~kg}(3.64 \mathrm{lb})]$ compared to other cultivars in 1999 (Table 2). 'Blues' and 'Yuki' also had above average head weight [1.21 and $1.17 \mathrm{~kg} /$ head $(2.67$ and $2.58 \mathrm{lb} /$ head $)$, respectively]. In 2000, 'China Express', 'China Pride' and 'Yuki' had the largest heads $[4.30,4.29$, and $4.19 \mathrm{~kg} /$ head $(9.48,9.46$, and $9.24 \mathrm{lb} /$ head $)$, respectively] and were significantly heavier than all other cultivars except 'Spring Flavor' at $4.01 \mathrm{~kg}(8.84 \mathrm{lb})$ per head (Table 2). In 2001, 'Blues', 'Summer Top' and 'Yuki' had heads more than $4.0 \mathrm{~kg}(8.82 \mathrm{lb})$ in size. Although head size of cultivars varied, depending on year, head weight of 'Yuki' was consistently above average over the 3 years tested. 'China Express' also had above average head size for the 2 years tested (2000 and 2001). 'Nikko' had the smallest head size in 2000 [2.92 $\mathrm{kg} /$ head $(6.44 \mathrm{lb} / \mathrm{head})]$ and 2001 [3.10 kg/head $(6.84 \mathrm{lb} /$ head $)]$. 'Optiko', 'Manoko' and 'Cha Cha' were also below average in head size for the 2 or 3 years tested.

There was a positive correlation between plant size and head size (1999, $r=0.82, P<0.0001, \mathrm{~N}=54 ; 2000, r$ $=0.65, P<0.0001, \mathrm{~N}=45 ; 2001, r=$ $0.41, P=0.0062, \mathrm{~N}=43$ ). 'Ohken 75' and 'Yuki' had the largest plant size in each of the 3 years tested (Table 2). 'Nikko' and 'Manoko' had the smallest plant size each year tested. 'Optiko', 'Akala', 'Summer Top', 'Orange Queen' and 'Cha Cha' also had below average plant size for each year tested.

Uniformity of harvest maturity was fairly consistent among cultivars, except 'Manoko' (rating of 2.8), which was less uniform in maturity than all cultivars except 'Blues' (rating of 3.2) in 2000. The uniformity of harvest maturity rating for other cultivars ranged from 3.7 to 4.2 (data not shown). The difference in uniformity of maturity among cultivars in 2001 was not significant $(P<0.05$, data not shown).

In 1999, when soft rot was not present, 'Blues' had the greatest percentage of marketable heads $(80 \%)$ and was significantly greater than 'Yuki' (51\%), 'TSX 4112' (46\%), 'Manoko' (28\%), and 'Summer Top' (21\%) (Table 2). Bacterial soft rot was the main reason for unmarketable heads in 2000 and 2001 and 'Blues' had a

Table 2. Harvest date [days after transplanting (DAT)], marketable heads (\%), head weight $\left(\mathrm{kg}^{\mathrm{z}}\right)$, plant size rating and soft rot $(\%)$ of $15 \mathrm{chinese}$ cabbage cultivars at Harrow, Ontario, 1999, 2000, and 2001.

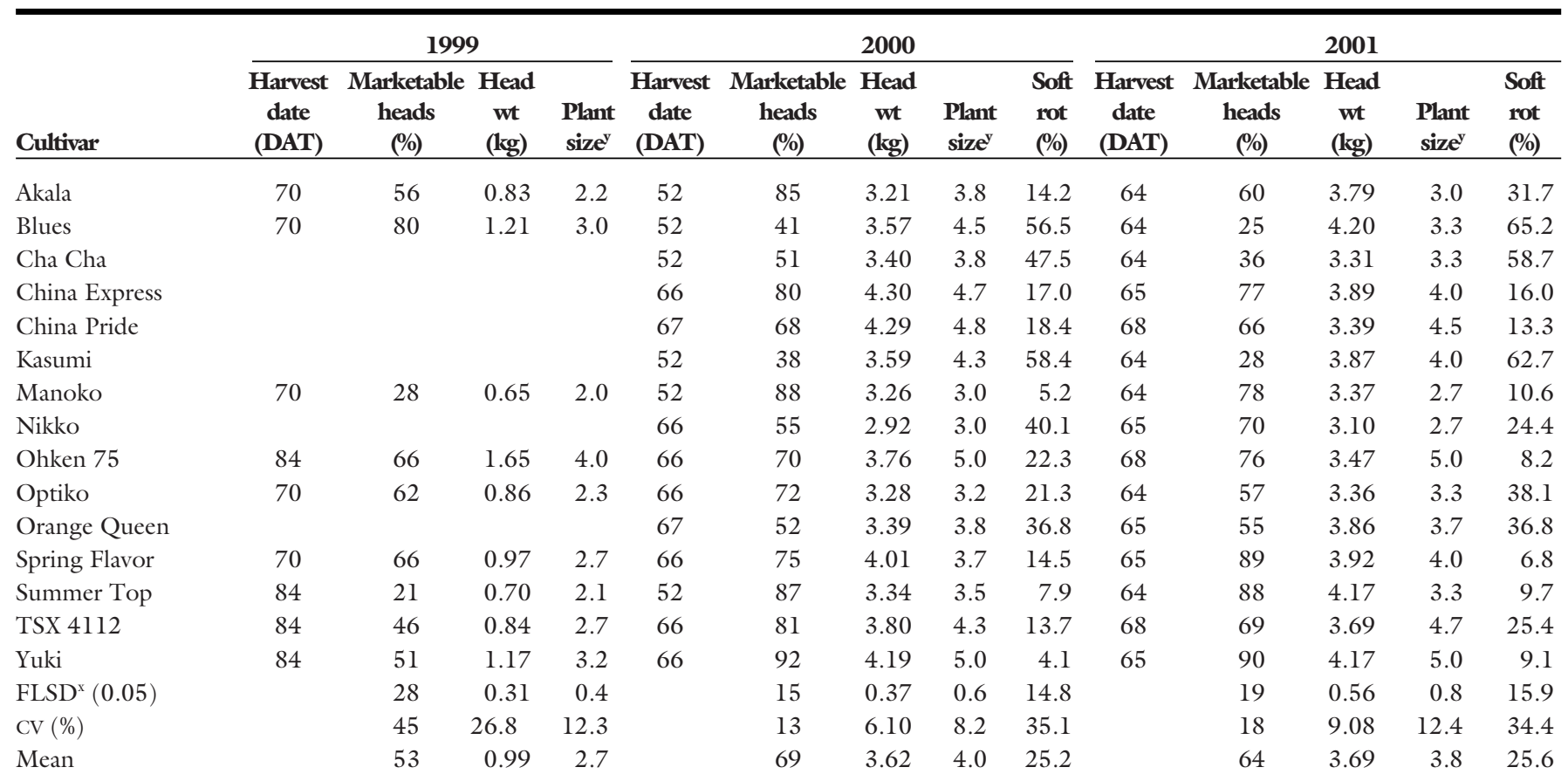

$\mathrm{z} 1.00 \mathrm{~kg}=2.205 \mathrm{lb}$.

y 1 to 5 rating: $1=$ low vigour, small plant size; 3 = moderate vigour; and $5=$ very vigorous, large plant size.

xFisher's least significant difference $(P<0.05)$ for values within the same column. 
Table 3. Number of spotted leaves per head and petiole spotting rating of nine chinese cabbage cultivars grown at Harrow, Ontario, at harvest and after 3 to 4 weeks in storage, 1999.

\begin{tabular}{|c|c|c|c|c|}
\hline \multirow[b]{2}{*}{ Cultivar } & \multicolumn{2}{|c|}{ Harvestassessment } & \multicolumn{2}{|c|}{ Storageassessment $^{z}$} \\
\hline & $\begin{array}{l}\text { No. of } \\
\text { spotted } \\
\text { leaves }\end{array}$ & $\begin{array}{l}\text { Petiole } \\
\text { spotting } \\
\text { rating }\end{array}$ & $\begin{array}{l}\text { No. of } \\
\text { spotted } \\
\text { leaves }\end{array}$ & $\begin{array}{l}\text { Petiole } \\
\text { spotting } \\
\text { ratingy }\end{array}$ \\
\hline Akala & 2.9 & 0.17 & $17.2^{* *}$ & $0.24^{\mathrm{NS}}$ \\
\hline Blues & 13.8 & 0.56 & $34.9^{\star \star}$ & $1.06^{* *}$ \\
\hline Manoko & 8.1 & 1.03 & $18.2^{* *}$ & $1.34^{\mathrm{NS}}$ \\
\hline Ohken 75 & 0.6 & 0.05 & $2.6^{\mathrm{Ns}}$ & $0.09^{\mathrm{NS}}$ \\
\hline Optiko & 5.2 & 0.17 & $27.7^{\star \star}$ & $0.43^{*}$ \\
\hline Spring Flavor & 3.1 & 0.13 & $24.4^{* *}$ & $0.38^{\mathrm{NS}}$ \\
\hline Summer Top & 2.7 & 0.18 & $9.8^{* *}$ & $0.23^{\mathrm{NS}}$ \\
\hline TSX 4112 & 6.5 & 0.41 & $13.7^{\mathrm{Ns}}$ & $0.29^{\mathrm{NS}}$ \\
\hline Yuki & 2.2 & 0.16 & $2.8^{\mathrm{Ns}}$ & $0.12^{\mathrm{NS}}$ \\
\hline FLSD $^{\mathrm{w}}(0.05)$ & 4.4 & 0.22 & 9.2 & 0.20 \\
\hline $\mathrm{CV}(\%)$ & 74.9 & 61.1 & 46.6 & 38.8 \\
\hline Mean & 5.0 & 0.30 & 16.9 & 0.43 \\
\hline
\end{tabular}

${ }^{\mathrm{z}}$ Assessed after 3 to 4 weeks in storage at $2{ }^{\circ} \mathrm{C}\left(36^{\circ} \mathrm{F}\right)$ and $89 \% \pm 5 \%$ relative humidity.

y 0 to 5 rating: $0=$ no spotting; $1=$ trace of spotting on the petiole; $2=$ some spots, scattered on the petiole; $3=$ moderate level of spotting; 4 = high incidence of spotting; and 5 = extreme incidence of spotting with entire petiole affected.

"Fisher's least significant difference $(P<0.05)$ for values in the same column.

Ns, ${ }^{*},{ }^{* *}$ Nonsignificant or significant at $P<0.05$ or 0.01 , respectively, compared to harvest assessment.

lower percentage of marketable heads in 2000 and 2001 because of soft rot (Table 2).

Bacterial SOFT Rot. Cerkauskas (1998) reported that bacterial soft rot caused major losses to chinese cabbage cultivars grown in Ontario, but no information was available on their relative susceptibility. Soft rot was often associated with injuries caused by cab- bage maggot, an insect vector, which aids in the dissemination of the bacteria (Balvoll, 1995). Environmental factors such as air temperature, relative humidity and moisture also affect the susceptibility of chinese cabbage to the soft rot bacteria (Fritz and Honma, 1987).

During the dry 1999 growing season (Table 1), only three heads over all the plots were affected by soft rot (data not shown). In 2000, a wet year, 'Kasumi' and 'Blues' had 58.4\% and $56.5 \%$ plant loss from soft rot, respectively, which was significantly $(P$ $<0.05$ ) higher than all other cultivars tested, except 'Cha Cha' (47.5\%, Table 2). 'Blues', 'Kasumi', and 'Cha Cha' had the highest levels of soft rot in 2001 (Table 2). 'Orange Queen' had above average loss from soft rot in 2000 and 2001 (36.8\% both years). Cultivars with less than $10 \%$ loss from soft rot in 2000 were 'Yuki' (4.1\%), 'Manoko' (5.2\%) and 'Summer Top' $(7.9 \%)$, and in 2001 were 'Spring Flavor' $(6.8 \%)$, 'Ohken 75' (8.2\%), 'Yuki' (9.1\%), and 'Summer Top' (9.7\%).

Although none of the cultivars tested were immune to bacterial soft rot, there were sufficient differences in

Table 4. Number of spotted leaves per head and petiole spotting rating of 15 chinese cabbage cultivars grown at $H a r r o w, ~ O n t a r i o$ at harvest, 2000 and 2001, and after 4 weeks in storage in 2000.

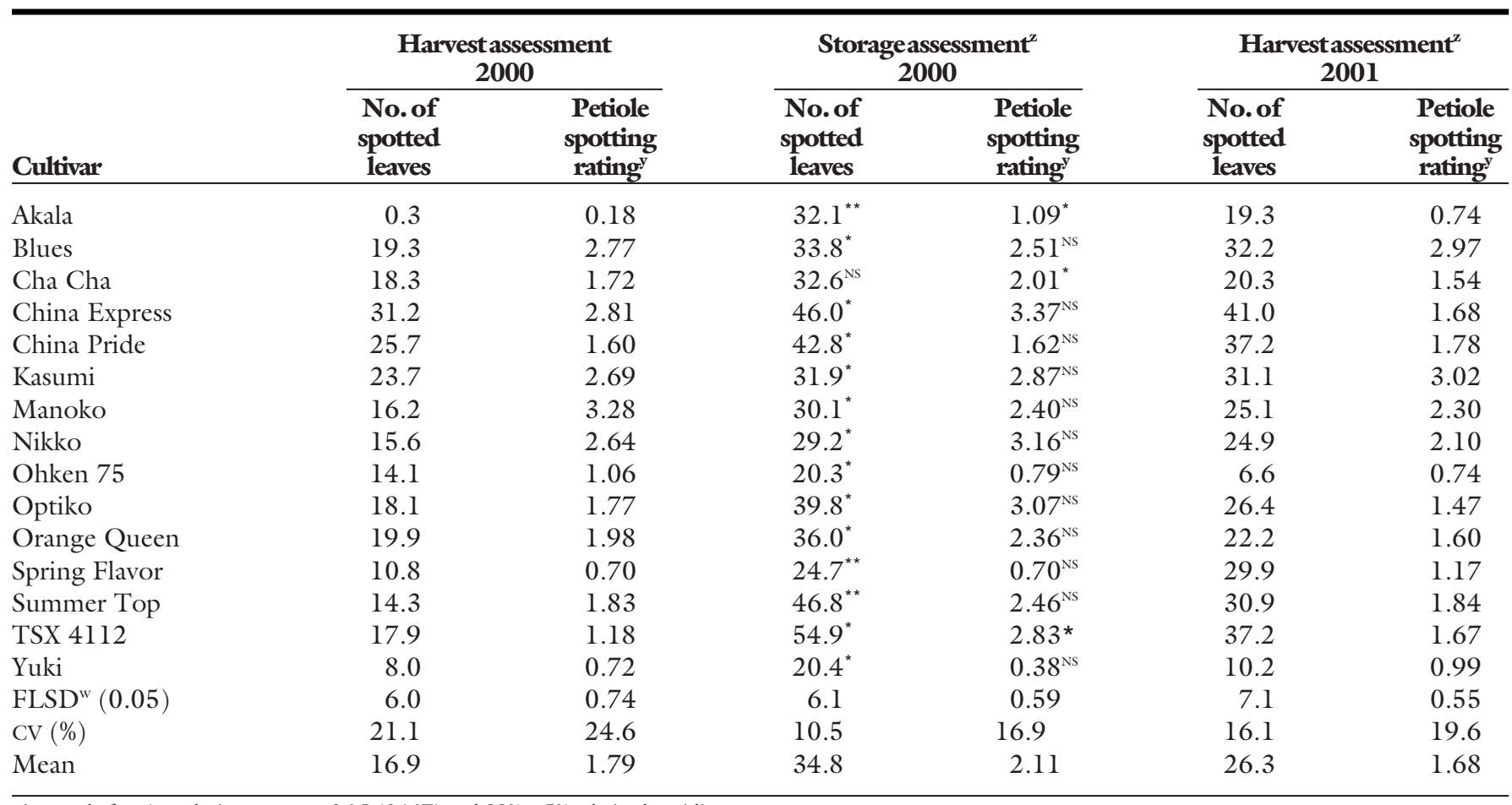

${ }^{\mathrm{z}}$ Assessed after 4 weeks in storage at $2{ }^{\circ} \mathrm{C}\left(36^{\circ} \mathrm{F}\right)$ and $89 \% \pm 5 \%$ relative humidity.

y 0 to 5 rating: $0=$ no spotting; 1 = trace of spotting on the petiole; $2=$ some spots, scattered on the petiole; $3=$ moderate level of spotting; $4=$ high incidence of spotting; and 5 = extreme incidence of spotting with entire petiole affected.

wFisher's least significant difference $(P<0.05)$ for values in the same column.

Ns, ${ }^{\star \star * *}$ Nonsignificant or significant at $P<0.05$ or 0.01 , respectively, compared to harvest assessment. 
cultivar susceptibility to suggest resistance as a useful method of control. Fritz and Honma (1987), Kikumoto (1981) and Togashi (1981) also reported growing resistant cultivars as an effective method of controlling soft rot in chinese cabbage.

Petiole spotting. The influence of cultivar, assessment time and their interaction were highly significant $(P<$ 0.01 ) in 1999 and 2000 for number of spotted leaves and petiole spotting rating. Consequently, the results are presented individually for harvest and storage assessments each year (Tables 3 and 4).

Petiole spotting started on the midribs of the outer head leaves and progressed inwards, depending on the cultivar and severity of the disorder. After 3 to 4 weeks of cold storage at 2 ${ }^{\circ} \mathrm{C}$ and $89 \% \pm 5 \%$ relative humidity, the number of spotted leaves generally increased and in some cases the number of spots also increased (higher rating). The number of spotted leaves increased during the storage period for most cultivars in 1999 (Table 3) and for all cultivars except 'Cha Cha' in 2000 (Table 4). The mean number of spotted leaves per head for all cultivars increased from 5.0 to 16.9 in 1999 (Table 3 ) and from 16.9 to 34.8 in 2000 (Table 4) from harvest to the end of the storage period. The mean petiole spotting rating either remained the same or increased during the storage period. Phillips and Gersbach (1989) also reported that the number of spotted leaves and intensity of petiole spotting increased during cold storage at $1{ }^{\circ} \mathrm{C}\left(33^{\circ} \mathrm{F}\right)$, reaching a peak between 14 and $28 \mathrm{~d}$ of storage.

In 1999, 'Ohken 75', 'Spring Flavor', 'Yuki', 'Optiko', 'Akala' and 'Summer Top' had only trace amounts of petiole spotting at harvest with ratings ranging from 0.05 to 0.18 (Table 3 ). These cultivars also had the fewest spotted leaves, ranging from 0.6 to 5.2 spotted leaves per head. However, 'Optiko', with 5.2 spotted leaves did not differ significantly from 'TSX 4112' and 'Manoko' with 6.5 and 8.1 spotted leaves per head, respectively. 'Blues' had the most spotted leaves (13.8), which accounted for about $30 \%$ of the head leaves by weight with petiole spotting (data not shown). After storage, all cultivars except 'Blues' and 'Manoko' had only trace levels of spotting with ratings from 0.09 to 0.43 (Table 3). 'Ohken 75' and 'Yuki' had the fewest number of spotted leaves (2.6 and 2.8, respectively) after storage.

In 2000 and 2001, the number of spotted leaves and petiole spotting ratings were generally higher compared to 1999 (Tables 3 and 4). This could be due to the better growing conditions and increased availability of soil nitrogen during the growing seasons of 2000 and 2001. High nitrogen fertilizer applications, especially as side dressing after head formation, are thought to contribute to the petiole spotting disorder (Takahashi, 1981; Phillips and Gersbach, 1989).

'Akala', 'Ohken 75', 'Spring Flavor', and 'Yuki' had only trace amounts of petiole spotting in 2000 and 2001 with ratings from 0.18 to 1.17 , depending on cultivar and year (Table $4)$. Cultivars with moderate petiole spotting ratings (>3) were 'Manoko' and 'Kasumi' at harvest in 2000 and 2001, respectively, and 'China Express', 'Nikko', and 'Optiko' after storage in 2000. In 2000, 'Akala' had the fewest spotted leaves at harvest $(0.3$ spotted leaves per head), which increased to 32.1 after storage. 'Ohken 75', 'Spring Flavor', and 'Yuki' had from 8.0 to 14.1 leaves with petiole spotting at harvest, which increased to 20.3 to 24.7 leaves with spotting after storage in 2000. The largest number of spotted leaves in 2000 occurred on 'TSX 4112' with 54.9 spotted leaves per head after storage. This represented over $80 \%$ of the head leaves by weight with petiole spotting (data not shown). In 2001, 'Ohken 75' and 'Yuki' had the fewest spotted leaves (6.6 and 10.2 per head, respectively), which represented $19.4 \%$ and $16.6 \%$, respectively, of the spotted leaves by weight. All other cultivars had over $50 \%$ of their leaves by weight with spotting (data not shown).

Differences in cultivar susceptibility to petiole spotting were reported in Japan (Takahashi, 1981) and Australia (Phillips and Gersbach, 1989), however, most of the cultivars tested were different from those commonly grown in North America. Phillips and Gersbach (1989) reported 'China Pride' as tolerant to petiole spotting and 'Kasumi' as highly susceptible. In the present study, 'China Pride' had lower petiole spotting ratings compared to 'Kasumi', however, the number of spotted leaves at harvest was not significantly different.
Petiole spotting occurred to some extent on all cultivars tested. However, in locations where this disorder is a problem, cultivars may be selected, which have a low level of petiole spotting (rating $<3$ ).

\section{Conclusions}

Chinese cabbage growers prefer cultivars with good horticultural characteristics, quality and yield and those that are resistant to soft rot and petiole spotting. Yield may be reduced from destructive diseases such as bacterial soft rot, which destroys the whole plant. However, a disorder such as petiole spotting, while not directly affecting yield, will reduce the quality and marketability of the product.

Although environmental conditions affected the performance of cultivars from year to year, cultivars were identified that consistently had low levels of bacterial soft rot and petiole spotting. 'Yuki', 'Manoko', and 'Summer Top' had less than $10 \%$ plant loss from bacterial soft rot in 2000 and 2001. 'Akala', 'Ohken 75', 'Spring Flavor', and 'Yuki' had relatively low levels of petiole spotting over the 3 years tested. With both diseases considered, 'Yuki' provided the best overall level of resistance. Strategies for field control of soft rot in chinese cabbage have been developed (Ontario Ministry of Agriculture and Food, 1996). However, for petiole spotting, although field strategies for control have been investigated (Warner et al., 2002), the optimum storage conditions may require elaboration as the spotting disorder increased for most cultivars.

\section{Literature cited}

Balvoll, G. 1995. Production of chinese cabbage in Norway: Problems and possibilities. J. Veg. Crop Prod. 1:3-18.

Cerkauskas, R.F., L.W. Stobbs, D.T. Lowery, L. Van Driel, W. Liu, and J. VanSchagen. 1998. Diseases, pests and abiotic problems associated with oriental cruciferous vegetables in southern Ontario in 1993-1994. Can. J. Plant Pathol. 20:8794.

Fritz, V.A. and S. Honma. 1987. The effect of raised beds, population densities, and planting date on the incidence of bacterial soft rot in chinese cabbage. J. Amer. Soc. Hort. Sci. 112:41-44.

Kikumoto, T. 1981. Studies on softrot disease of chinese cabbage in Japan, p. 
113-127. In: N.S. Talekar and T.D. Griggs (eds.). Chinese cabbage: Proceedings of the first international symposium. Asian Veg. Res. Dev. Ctr. Publ. 81-138.

Kim, B.S. and A. Klieber. 1997. Quality maintenance of minimally processed chinese cabbage with low temperature and citric acid dip. J. Sci. Food Agr. 75:31-36.

Nishi, S. 1981. Hakuran, an interspecific hybrid between chinese cabbage and common cabbage, p. 385-391. In: N.S. Talekar and T.D. Griggs (eds.). Chinese cabbage: Proceedings of the first international symposium. Asian Veg. Res. Dev. Ctr. Publ. 81-138.

Ontario Ministry of Agriculture and Food. 1996. Major diseases of ethnic crucifers, bacterial soft rot. Chapter 5, p. 1. In: J. Schooley (ed.). Integrated pest management for crucifers in Ontario, A handbook for growers, scouts and consultants. Ont. Min. Agr., Food and Rural Affairs, Toronto.

Ontario Ministry of Agriculture and Food. 2000a. Area, production and farm value of specified commercial vegetable crops, Ontario, 2000. 4 Mar. 2002. <http:// www.gov.on.ca/OMAFRA/english/ stats/hort/vegsum00.html>.
Ontario Ministry of Agriculture and Food. 2000 b. Vegetable production recommendations 2000-2001. Publ. 363. Ont. Min. Agr. and Food, Toronto.

Phillips, D.R. and N.B. Gersbach. 1989. Factors influencing petiole spotting (gomasho) in chinese cabbage. Acta Hort. 247:117-121.

Shattuck, V and B. Shelp. 1986. Chinese cabbage production in southern Ontario. Ont. Min. Agr. and Food, Toronto, Agdex $252 / 20$.

Takahashi, K. 1981. Physiological disorders in chinese cabbage, p. 225-233. In: N.S. Talekar and T.D. Griggs (eds.). Chinese cabbage: Proceedings of the first international symposium. Asian Veg. Res. Dev. Ctr. Publ. 81-138.

Togashi, J. 1981. Studies on relationship between varietal difference of chinese cabbage in resistance to the soft rot disease and growth of the causal organism (Erwinia carotovora) in rhizosphere soils. Bul. Yamagata Univ. Agr. Sci. 8:657-663.

Warner, J., R. Cerkauskas, T. Zhang, and $X$. Hao. 2002. Nitrogen management and cultivar evaluation for controlling petiole spotting and bacterial soft rot of chinese cabbage. Can. J. Plant Sci. 82:225-226 (abstr.). 